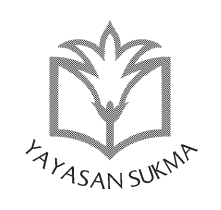

SUKMA: JURNAL PENDIDIKAN

ISSN: 2548-5105 (p), 2597-9590 (e)

Volume 2 Issue 1, Jan-Jun 2018, hlm. 67-92

https://jurnalsukma.org/index.php/sukma/article/view/02103

\title{
STUDENTS' CRITICAL THINKING SKILLS IN GROUP DISCUSSION \\ The Case Study of Fifth Grade Students in Sukma Bangsa Bireuen Elementary School
}

\section{Asrita; Nurhilza}

University of Tampere, Tampere, Finland

email: asrita1580@gmail.com

\section{Abstract}

This study is concerned with group discussion as one of the teaching methods can identify the emergence of students' critical thinking skills in fifth grade students of Sukma Bangsa School. The purpose of this study was classified fourteen critical thinking concepts (practice, action, management, appreciation, awareness, care, evaluation, understanding, analysis, appraisal, interpretation, being, reflection, reviewing) which emerged in the learning process using group discussion. The study showed that eleven critical thinking concepts (practice, 
action, management, appreciation, awareness, care, evaluation, understanding, analysis, appraisal, interpretation) could be found in fifth grade students, while three of them are missing (being, reflection, reviewing). It could be concluded that the students' ability to think critically was developed after getting experiences in learning by using group discussion. However, an important factor in fostering students' critical thinking skills was teachers' involvement. Thus, teachers need to fully participate to stimulate students to express their critical thinking skills in the learning process.

[Artikel ini membahas tentang diskusi group sebagai salah satu metode mengajar dapat mengindentifikasi terbentuknya kemampuan siswa dalam berpikir kritis terutama siswa kelas 5 di Sekolah Sukma Bangsa. Tujuan dari penelitian ini adalah mengklasifikasi 14 konsep berpikir kritis (praktik, aksi, manajemen, appresiasi, awareness, peduli, evaluasi, pemahaman, analisa, appraisal, interpretasi, being, refleksi, dan mereview) dapat muncul dalam proses pembelajaran dengan menggunakan diskusi group. Hasil penelitian menunjukkan bahwa tujuh konsep berpikir kritis (praktik, aksi, managemen, appresiasi, awareness, peduli, evaluasi, pemahaman, analisis, appraisal dan interpretasi) telah ditemukan pada siswa kelas 5, sementara tiga lainnya tidak (being, refleksi dan review). Sehingga dapat disimpulkan bahwa kemampuan siswa untuk berpikir kritis telah terbentuk setelah melalui proses pembelajaran dengan menggunakan diskusi group. Meskipun fakor terpenting untuk memunculkan kemampuan siswa berpikir kritis adalah keterlibatan seorang guru. Maka guru-guru perlu berperan aktif menstimulasi siswa untuk mengeluarkan kemampuan berpikir kritisnya dalam proses pembelajaran.]

Keywords: elementary school, group discussion, critical thinking 


\section{A. Introduction}

Students' critical thinking skills can be formed with an educational system which guides the students to be close and sensitive to their environment. The learning process is not only concerned with things that are theoretical. The lessons given should be explored in depth and applied in everyday life. One of the learning purposes is to help develop the critical activities and mindsets of students. It should be developed as much as possible according to the abilities of each student. In this case, teachers need to provide students the opportunity to think freely in accordance with their interests and abilities. Class activities which consist of ideas will stimulate students to think critically.

The quality development of Sukma Bangsa School as written in its blueprint refers to the concept of quality assurance. A strong emphasis is given to the process, not only to results or student achievement. The quality assurance concept demands optimal participation of teachers in designing and implementing the learning process. The ability of students to take the initiative, risk, be critical and brainstorm in groups are some of the important things the quality development of Sukma Bangsa has embraced so far (Fachruddin, Kusumaningrum, Dewi and Maulana 2005).

One method capable of attracting the students' attention is a group discussion, by which it is believed that students can interact with teachers and each other more deeply. By using this strategy, the teachers may hope that the students will follow the learning process as well. Moreover, since student ability to think critically is an objective of learning that is often expressed in primary schools (Florea and Hurjui 2014); it is not an exaggeration to say that the teachers may apply the group discussion strategy to improve the students' capacity to think critically.

In addition, we had an interest to know the differences in the learning process in using the group discussion method and lecturing method related to the development of students' critical thinking skills. We assumed that lecturing can be a passive 
method or ineffective in fostering the important factors in student learning such as students' interest, interaction and engagement. However, in contrast, research by Collen (2009) compared two methods consisting of lecturing and group discussion in developing student ability to think critically, and they found that there was no significant difference in both teaching methods for increasing students' critical thinking ability. Indeed, we aimed to show the kinds of student's critical thinking skills emerging in discussion by observing the variety of their activities in group discussion and their worksheets.

This research was a qualitative research which had been participated by all students from fifth grade A and $B(5 \mathrm{~A}=26$ students and $5 \mathrm{~B}=24$ students) and two classroom teachers. We used observational methods to find answers to our research questions. In the field, we recorded all the activities during the learning process in the classroom by using a digital camera. We also noted the students' communication in each group using the recorder. We observed the process of group discussions in two classes of the fifth grade at Sukma Bangsa Bireuen.

After doing the observations, we discussed and shared the information that we got based on our notes. When transcribing the data, each of us was responsible for one class. We transcribed the video verbatim, which was beneficial in providing all the data needed. Then, we compiled our verbatim transcripts to assure our perception when organizing the data. Finally, we used the same concepts to categorize or theme our data. Practically, the researchers had to look back to the data transcripts when writing the findings and discussions. It was helpful to check the match between the data and the findings.

\section{B. Critical Thinking}

According to Vygotsky, the concept of the Zone of Proximal Development (ZPD) distinguished between the actual development level and the potential level of the pupils (Oakley 2004). However, each pupil would be able to develop their ability from 
virtual level to the possibility level at any point in time. Vygotsky thought that each pupil was able to develop their capacity during learning process if they were helped by the other experts. Those experts could support the pupils to increase their capacity in thinking critically and enhance their achievements.

Critical thinking is one of the basic skills that promotes the learning environment as an interesting action, various methods in teaching and learning are used, relying on conditions of pedagogic factual and development stages in thinking critically (Florea and Hurjui 2014).According to Florea and Hurjui, critical thinking is a step to approach and to solve problems based on thinking in a way which is persuasive, logical and gives rational arguments. This step is implicated to verifying the data, evaluating the process and choosing the appropriate answers to the task that has been given. In line, the students should properly reject the answer that they think are incorrect, and then provide other alternative solutions by giving rational reasoning. They also stated that thinking critically is an active, conformed, and complicated process, such as reading and writing, speaking and listening, which includes the way of thinking to accumulate the knowledge in the beginning and closes with a good solution. In addition, they described that thinking critically is a result that can be obtained by someone's own thinking. Everyone has critical thinking for the basic step of associating the new concept with other input.

Moon (2004) also explained that thinking critically is the capacity to examine the information from many sources. This information would be processed in a creative and rational way. It also will challenge, and will involve analyzing and making conclusions. Thus, the result can be defended and justified. Because the context and its meaning always change, the knowledge has to be constructed.

Based on the research conducted by Moon (2004), there are several activities of critical thinking assumed by the teacher. However, the ideas might be different based on different activities and dissimilar teachers who apply them. Below are several 
activities of critical thinking, for example: 1) Reviewing of others' arguments. In this case the task of the critical thinker is to review the process of developing an argument and the process of reaching a conclusion. The students review someone else's arguments when they discuss in groups, such as during speaking and writing to complete the task. 2) Evaluation of an object. The students should think critically in forming an evaluative judgment of an object, such as a work of art, a form of task presentation, and so on. In this step, the critical thinker must think creatively. Furthermore, they can evaluate an object that has been developed by others. 3) Development of an argument. In this step, the argument is built by a critical thinker, such as preparing the presentation with his/her own words, reasoning and decision making. However, the students often face issues when presenting their arguments, especially a lack of structure in writing or speaking. Further, the student should use this process in other tasks that will they do.

Also, 4) thinking critical about oneself. This term is often expressed as well-known learning reflection or reflecting critically, (Brockbank and McGill 1998; Fisher 2003 as cited in Moon 2004), even though it could be focused on activity by improving the new idea. Because the self is connected to any other forms of critical thinking, the issues relevant in critical thinking about the self can be a part of other forms of thinking critically. 5) Analyzing the case. The teacher often demands that the students think critically about what is happening during the learning process. The purpose of this step is to involve the students in reviewing their activities and thinking how matters have been managed by them. Moreover, it will consist of thinking critically about self. As a result, the students become more reactive to every single event that happens to them. And 6) Participation in developing answers to the arguments of others. The students who participate in arguing with their mates' opinions perform the next action in thinking critically. Here, the students must think deeply to examine the background of the argument and how to respond to it. In addition, they can respond to the argument by speaking 
or writing. In other words, the student can use many ways to present their opinions.

\section{Group Discussion}

Group discussion is a technique in which students work together in small groups to reach the same purpose. Small group discussion, which usually consists of four or five students, is regarded as a potential solution to modify the format of large classes (Jones 2014). The researcher said that group discussion is a "circle of knowledge" meaning working in a team to discuss the lesson collaboratively in a circle position. Students work together in order to develop anything that did not exist before the collaboration (Peters, Joseph and Armstrong, 1998). In conclusion, the purpose of the collaborative learning concept as well as the grouping and pairing of students' is to achieve an academic goal.

Burke (2011) stated that an important focus in pedagogical change is active learning, which consists of collaborative learning or small group work. According to Beebe and Masterson as cited by Burke (2011), the benefit of group discussion is that it provides more information, and greater resources from different backgrounds and experiences. Moreover, group discussion can stimulate creativity and foster students' comprehension. A learning method which promotes elaboration, such as collaborative work, could improve the academic achievement of the students (Blankenstein, Dolmans, Vleuten and Schmidt 2011).

On the other side, learning by using the group discussion method is related with the teacher-student relationship. According to Liberante (2012), the emerging bond among teacher- students becomes the potent element in the process of learning. Hughes and Chen $(2001,278)$ stated that supportive and positive relationship between teacher and students ultimately promotes "a sense of school belonging' and encourage students to "participate cooperatively in classroom activities".

Students can learn many things which can help in improv- 
ing their critical thinking skills through group discussions. Dikici and Yavuzer (2006) as cited by Karami, Pakmehrand Aghili (2012) considered that, compared with individual activities or competition, the outcome of learning collaboratively is better. In addition, previous researchers' findings have exposed that in the higher education system there is a positive result of collaborative methods on the cognitive levels of the students and their abilities to learn (Jacobs, Ott and Yvonne Ulrich 1997; Celuch and Slama 1999 cited by Karami et al. 2012).

Moreover, critical thinking skills are associated with problem solving or collaborative learning. This is because the ability to think critically affects all forms of communication, including speaking, listening, reading and writing (Macknight 2000). On the other side, appropriately structured cooperative learning provides continuous support and advice from other students and the teacher that fosters the student to show their critical thinking skills (Cooper 1995). Nelson (1994) argued that critical thinking skills in collaborative learning could modify the education to become more effective than individual learning. Students in a group learning environment are doing and learning everything together. At the end of collaborative work, all of the group members must be able to demonstrate the discussion product. Students require the ability to think critically in order to be able to deliver the things that they learned ethically (Matchett 2009).

Students' ability to think critically can be developed through collaborative learning. The implementation of the group discussion method emphasizes students' mastery of the concepts of the material to solve a problem through a process of critical thinking, self-confidence and the ability to interact with friends and the social environment. Harter (2009) believed that critical thinking should collaborative due to three things, as follows: Firstly, many critical thinking skills are shown by students in a collaborative activity. Secondly, working in groups is an instrument that facilitates students to learn how critical thinking skills can be improved. Lastly, critical thinking in collaborative learning 
teaches students to respect each other as an ethical value. In addition, Davidson and Worsham 1992; Klimoviene, Urboniene, and Barzdziukiene as cited by Fung, To and Leung (2016) argued that there are satisfactory data to support that work in groups is valuable in improving students' ability to think critically.

\section{Critical Thinking in Elementary Students}

Kettler (2014) stated that only a small number of researchers who have observed critical thinking skills among the elementary student population. Generally, the literature on critical thinking focuses on older students, such as college students. Previous studies by Kettler (2014) identify that there is a relationship between critical thinking and the cognitive ability of the students. The results of his study also prove that the development of students' critical thinking ability exists in early fourth grade. Related to this case, Piaget's theory of cognitive development stated that the cognitive maturity of children is divided into different stages. Their brains develop through the natural process of maturation which influences their understanding about the nature of and their capabilities to analyze the current development of the world. However, Piaget also considered relations with the environment as a vital aspect in cognitive development (Oakley 2004).

A previous study was reported by Malamitsa, Kasoutas and Kokkotas (2009) who observed the improvement of students' ability to think critically in science in upper grades of elementary schools. It suggested that the improvement of students' ability to think critically and meaningful learning can be reached by creating opportunities for students to engage with parts of science. In fact, the ability of the students to think critically is not the direct result of specific subjects, such as mathematics or social science. Students do not automatically have this skill. It is a skill that must be taught by teachers. As stated by Massa (2013), numerous studies of critical thinking have proved that the ability to think critically can be taught. This suggests that teachers, who 
have a function as facilitators, motivators and evaluators, should be competent in fostering students' critical thinking skills.

Moreover, grade five students, as found in Sukma Bangsa School, were able to work on inquiry related to a lesson. Students were capable of being engaged in reading books individually or with partners. Many of the upper primary students had the ability to ask questions either with teachers or friends if they found certain difficulties. Additionally, students also showed their ability to comment on the things which happened around them. Most of them had been able to develop their own arguments in following the learning process. On a particular theme, students gathered in a group and participated in discussion or collaborative activities. Students' conversations in a group guided them to integrate their knowledge and experience to complete their discussion task. It was therefore evident that fifth grade students were showing their ability to think critically.

Additionally, critical thinking in the fifth grade can be promoted by asking them questions. For example, the teacher could ask students to write evaluation papers on the most interesting things they learned in class today, and what single thing they still feel confused about. They would complete this activity after the learning process, but before the class ends. The teacher then gets feedback about the learning process, especially about what the students have learned and what they still need to know. Further, it helps the teacher to organize his/her strategy in teaching and makes it easier to conduct classroom assessment. Also, in this way, the students can improve their skills in writing and critical thinking.

The other thing to improve the critical thinking of the students in grade five is to encourage them to ask questions during learning process in the class. The teacher should respond positively to their questions at all times, without forcing the students to a certain extent and giving punishment for their mistakes, so as to make them express their ideas easily and freely. Thus, the students' questions can be seen as their process in developing 
their critical thinking about what they have said (Schafersman 1991).

\section{E. Findings}

The learning process in the fifth grades classes A and B was conducted by the classroom teacher on the topics of "Indonesia's Strategies in Overthrowing the Colonizers" and "Creating the TV Advertisement". Students were asked to discuss the strategies of how Indonesian people conquered the colony, while the aims of advertisement lesson were that the students developed their creativity to create an advertisement and present it in front of the class through role play. Several critical activities showed by students during the group discussion processes that were observed in both fifth grade classes.

\section{Practice}

One critical thinking labelled as practice was the students' habit to stand up and answer the greeting from the teacher at the beginning of the class. This was a common activity of critical thinking, which emerged in every teaching method used by the teacher. Especially in collaborative learning, students always greet their friends when opening or closing their presentation in front of the classroom. The extraordinary thing related to this critical concept was students' complaints when their friends did not follow this kind of habit. They also said "thank you" after presenting the discussion task or when they got something from their friends or teachers. The other routine that students did was saying "I am sorry" when they made a mistake toward their friend or the teachers.

\section{Action}

Action was one of the critical thinking categories seen from students, who directly read their reading material without any instruction from the teacher. It happened spontaneously when 
they were directed to sit in a group. Students were engaged in reading the handout. Moreover, students who needed more explanation or were still unclear about the discussion task had the initiative to ask the teacher by calling him/her to come over. The other action found in the learning process by discussion in a group was interaction among students. The interaction occurred not only between students in the same group, but it also happened between students from different groups. Gillies (2003) argued that activities in groups are designed to support students to think about the problem more deeply before trying to solve it. Thus, the students should be challenged to engage in meaningful interactions with their mates to gain the contribution of the learning. In fact, the connections built in groups might not relate to the task they needed to discuss, such as joking or talking about something out of the lesson context. Furthermore, agreement to make a copy the result of the discussion on their own papers before presenting was an action seen to be done by all students involved in the group discussion. Surprisingly, at the end of the discussion process in the fifth grade A class, we found that a student enjoyed drawing a picture on her paper while waiting for the presentation session.

In the fifth grade B class, students in the group got the task to create a TV advertisement. Every group began the discussion by asking "What should we do?" By asking a particular question or providing a suggestion, this would transfer the student to a higher level in critical thinking. This is the characteristic of the student who is in the zone of proximal development (Vygostky as cited in King 2012).

Furthermore, the students discussed about kinds of action they would do to complete the task. They shared the acting roles in presenting the advertisement. There were the students who acted as people who had problems with their teeth, stomach, spiciness, scratching, and jogging. Their actions were; "Hmm... very spicy" (some of group members were eating meatballs), "Ouch... my teeth are bad because I really like to eat candy" , "Ouch... something's wrong with my stomach, I want to eat some biscuits", 
"Stop, stop! Let's sit a moment" (acting to stop the jogging), "I was bitten by mosquitoes" (a student scratching himself).

\section{Management}

The critical thinking ability of management appeared from several students' activities in the learning process using group discussion. Learning by using group discussion began when the teacher divided the students into small groups consisting of four students, grouping by number. According to Lou et al 1996 as cited by Gillies (2003), the advantages of small group work increases when the group's members do not exceed four members and the groups are mixed in gender and abilities. In this activity, the classroom situation was very crowded; students tried to find their group members by asking "Who gets number one?" (other students mentioned other numbers). Then students who got the same number would gather in a group. They set the place and their own comfortable position to settle the discussion task by instructing the group members, such as: "We sit here", "Our group will be in that corner", "Here is our place", and "Let's discuss there".

Furthermore, they chose one group member as a note taker in the discussion. After finishing the process of the discussion, they managed their contribution to the group's work by dividing presentation turns. The conversations were such as: "We open the presentation simultaneously", "One of us reads the question and the answer will be read by another", "I will be the first speaker", "You read this number and he will continue to the next number".

Especially for the group advertisement task, they divided the roles to each group member in order to master the action in showing the advertisement of a product. We noticed there was a group member appointing one of their friends to act as a particular actor; "You pretend to be the one with stomach-ache", "You come while scratching your body", "You run around us", and "We will act like this". 


\section{Appreciation}

Appreciation could be seen when they decided to pay attention to watch their friends' presentations. They listened to the explanation from the group who stood in front of the class to deliver the discussion results and to perform the advertisements. After watching the presentations, the student viewers applauded it. They also showed respect when the groups performed a funny story or amusing action by laughing. They always proudly supported the group members when they spoke incorrectly, without teasing them. These activities indicated that students had shown critical thinking skills in learning by using group discussion.

\section{Awareness}

Awareness can be seen when the teacher asked who was missing from the class, the students directly mentioned their friends' names and the reasons for their absences. Moreover, one student raised his hand and said affirmatively, "I don't get it yet", when the teacher divided the reading material and asked them who did not get it yet. These kind of activities indicated that students were basically able to express their critical thinking skill.

\section{Care}

In order to avoid the disturbance of their concentration during the discussion process, students hinted at their friends to be quiet. They expressed it by saying "Hush...keeps silent please!" or "Don't make a noise please!" These kinds of students' activity showed their critical thinking ability to care for each other. As described by Smith (1996), through collaborative activities, students obtain beneficial outcomes to themselves and other group members. Typically, working in groups is more than being physically near to other students, it also generates greater productivity such as caring, helping and sharing. Stating this differently, King (2012) said that students have to acquire how to understand the aim of the subject matter, focus on the assignment, motivate their mates to address the issue, and keep giving 
positive comments, admiration and positive feedback.

Especially in fifth grade B class, five groups had shown how they cared about their friends when some of them had problems with their acting. They respected their friends by asking "What happened to you?" They also motivated their friends by whispering what their group member should do when they forgot the text or actions during the performance of the advertisement. Other students who watched the performance gave support to the actor without mocking them. Coles and Robinson (1991) as cited in Moon $(2004,47)$ described that "use the notion of critical thinking as a disposition in order to emphasize some positive characteristics of what they see as the effective critical person - a 'respect for persons, readiness to consider alternative explanations, care for the procedures of inquiry, readiness to listen to others, a habit of judicious suspension of assent and a habit of self-appraisal'

\section{Evaluation}

Furthermore, the group discussion can emerge the students' ability to evaluate whatever happened in their group when completing the task. The students said, "How do you think about our plan?" or "Why do you do like that?" We can include these activities into one skill of critical thinking. In this skill, students can evaluate the progress in their group discussion by asking each other in finishing all steps. They discussed to ensure all steps in the task form were done or if they still needed to add some ideas. On other hand, they also informed each other about their performance in practicing the role play. Sometimes, the students asked the teacher to evaluate and give feedback their performance in practicing.

\section{Understanding}

Further, students' ability to respond to their friend's opinions in a discussion proved that they had critical thinking skill in the form of understanding. When students responded to 
their friend's view, it meant they understood what their friend was talking about. For example, a student asked his friend "Why do you drink the fresh tea?", and his friend responded that "Because fresh tea is very fresh and has a good taste", and the students also said "Yes, I agree with you." The response could be their desire to know more or to ensure themselves about something. Smith $(1996,1)$ expected that "the more students work in cooperative learning groups the more they will learn, the better they will understand what they are learning, the easier it will be to remember what they learn, and the better they will feel about themselves, the class, and their classmates".

Moreover, the students responded to the teacher's explanation about the topic when he wrote on the whiteboard. In line, they also showed a positive reaction when the teacher asked about what kinds of product they would present in the advertisement. In addition, the student could answer the questions on their understanding about the steps in the formation task which had to be completed by them.

\section{Analysis}

Students' ability to analyze the topic in group discussion is claimed to emerge from critical thinking skills. One way to foster critical thinking skills in learning is by allowing students to be creative in discussing the lesson. In this case, a student associated the discussion task with a war movie. Critical thinking happens when students analyze movies, through which they can then learn how to make judgments and decisions, interpret information and draw conclusions related to their discussion task.

In addition, when the students started to understand and analyze the teachers' instructions about the task, it provided one way to emerge critical thinking skills. It happened while the students created the steps of an advertisement. Ideally, all members in group discussion should participate and be active when they conducted the discussion session.

According to Jennifer Moon (2004) collaborative learning is 
a form which provides a way for the students' ability in analyzing, synthesizing and evaluating their ideas through a cooperating system. Generally, the students will be able to share their ideas through interaction in discussion. It is clear that by interacting the students can learn from each other, especially accepting the other's ideas, and how to respect to the judgments and reflections of others.

\section{Interpretation}

The other skill in thinking critically is interpretation. It can be seen from the explanation that the student demonstrated this ability. In this case, in the fifth grade A class, all groups members got turns to present the discussion results. Most of them stood in front of the class with confidence. Only a few students seemed less confident when making a presentation. It could be seen from their expressions such as nervousness, embarrassment, and covering their face with a book. However, the presentation was conducted only in a short time, to answer questions based on their reading material. Most of them presented the discussion results by reading notes without any additional explanation. Only one student in one group delivered her presentation without any notes.

On the other side, the aim of the group discussion in fifth grade B class was to present good steps in creating an advertisement. Each discussion group also had to perform a good advertisement in their role play. One of the categories for a good advertisement is showing the product as interestingly as possible. So, the students explained the benefits of the product and persuaded the consumer using logical reasoning.

\section{Appraisal}

The next skill in critical activity that was shown by the students in group discussions was appraisal. The students persuaded others about the advantages of the product which they had presented. This activity related to interpretation, a skill used 
whenever the students express their ideas to influence others by giving a clear statement and supporting logical reason. Such as "the toothpaste treats the problems with my teeth. That's why you should use this toothpaste. And all of you must brush your teeth three times a day." Perhaps, they persuaded, the product that they had was the best one. They gave an opinion about the condition and the importance of something to the others. Further, the students will be accustomed to think critically about other issues that will face in the future if they commonly use interpretation and appraisal skills. Additionally, they can develop their capacity in thinking and understanding the issue. Then, they will try to solve problems by appraising them. The students will find it easier to persuade others if they are capable of providing arguments to others using supporting evidence: true or false, clear or unclear, acceptance or rejection.

\section{F. Discussion}

Generally, discussion in the learning process aims to train the students' ability to think, namely through the expression of ideas, opinions, comments, criticisms, and so forth. Several things that should be prioritized by the teacher in conducting group discussion are avoiding the action of the students who dominate the discussion, by giving a chance to other students considered as reticent and providing a stimulus to them. Moreover, teachers should encourage students to respond to the conversations of other friends, so that the interaction between all participants occurs. Teachers also should avoid students' simultaneous responses, so that every student can individually express their thoughts freely, based on their own understanding.

The teachers' task becomes more directional when they can manage the class appropriately. Classroom management is an activity that must be prepared by the teacher before teaching. Particularly when using group discussions, teachers should consider accessibility, mobility and interaction of students. Teachers should ensure that the place for the discussion is con- 
venient for all participants. When forming the groups, teachers must pay attention to the number of students in a group. The numbers of students in a group should usually consist of 4 or 5 students, or it can be adjusted by the number of students in the classroom. Moreover, the number of groups in one classroom also must be considered. If the number of groups in a classroom is too many, teachers will find it difficult to guide them in the discussion process. Most importantly, the composition of the students in a group must be created by considering gender and ability. Indeed, in students' arrangement in the group it is advisable to combine gender and individual capabilities.

Students' ability to think critically is not a new model in learning. It relates with Bloom taxonomy, which regards that critical thinking is a combination of the abilities to analyze, synthesis and evaluate knowledge. For example, on a particular theme, students' ability to think critically can be identified from their questions about the causes of the phenomena around them. When students get the answer and correlate it with other knowledge, then draw their own conclusions, this means the abilities to analyze, synthesize and evaluate have been combined. As previously discussed, students' critical thinking skills also can be identified from their problem solving capabilities. For example, when they find a withered flower in front of their class, they will change its position and start watering the flower.

On the other hand, discussion is an appropriate way to develop students' critical thinking skills. Therefore, a teacher who should teach students to think critically can encourage them to discuss with each other. Teachers should support the students to express their arguments and explain them to their friends. In this case teachers also can stimulate them by asking simple questions or making statements. Nevertheless, discussions may not be productive if students do not prepare well.

The ability to think critically can be seen from several aspects, such as writing and discussion. Teachers who want to know about students' critical thinking skills can ask them to write 
a description of a phenomenon. The teacher also can ask students to write a short story about the events seen or experienced. Additionally, students can be asked to discuss while teachers observe the way they ask and answer questions related to the issue.

\section{G. Conclusion}

This study found that fifth grade students of Sukma Bangsa elementary school showed eleven of the critical thinking categories. The critical thinking categories showed by students were: practice, action, understanding, appraisal, analysis, evaluation, management, appreciation, evaluation, care, awareness, and interpretation.

According to our findings, the researchers claim that the students in fifth grade at Sukma Bangsa School regularly applied their critical thinking, especially action, appreciation, care, awareness and practice. It happened because those categories had become a habit for them. Additionally, the habit had been constructed earlier in the first grade. Thus, it had become ingrained for the student.

Furthermore, the school components, such as the principal and teachers, have tried to develop many activities in the classroom to increase students' thinking consistently. On the other hand, the teachers also created a good lesson plan when teaching the students. The content of the lesson plan that was created showed a good step in encouraging the students' critical thinking.

In addition, the other categories such as understanding, evaluation, management, analysis, appraisal, and interpretation were also shown by the students in the fifth grade at Sukma Bangsa School. In reality, not all students could build their critical thinking for those categories. Mostly the students who can express their skill in critical thinking are the students who have good abilities in thinking. The students' critical thinking can also emerge if the teacher and peers help them. In this case, the teacher can provide good instructions while the students are completing their task. Moreover, the teacher should offer good questions to 
stimulate their thinking; the students also can express new ideas with the support of their peers in group discussions. As a result, these strategies not only increase the students' confidence to talk to each other, but also to express their opinions.

On the other side, this study revealed that a learning process by using group discussion could facilitate students to express their critical thinking skills. All types of group discussions provide them more opportunities to speak. Students' conversations in group discussion played an important role in reaching the learning goal. Numerous general comments in the discussions such as: "Look at this!" (a member pointing to an information), "Maybe we must read it to find out more on this" (searching for information needed); "It looks like they will tell us more about it" (problems they were trying to solve). The conversations among group members served to mediate each other's learning by giving explanations, focusing attention on the problem of the discussion, and challenging each other's perspectives on important points related to the task. This interactional process involved the students in reciprocal interactions that served to mediate and scaffold their learning, which would be a critical to the success of the groups (Gillies 2003). Therefore, students' ability to think critically and their capacity to express opinions will develop after getting experiences in collaborative learning. 


\section{BIBLIOGRAPHY}

Barnes, D. L. 1970. "Identifying and Using Critical Thinking Skills In The Elementary Classroom.” The Teacher Educator 6 (2): 7-16.

Blankenstein, F. M., Dolmans, D. H., Van Der Vleuten, C. P., \& Schmidt, H. G. 2011. "Which Cognitive Processes Support Learning During Small-Group Discussion? The Role of Providing Explanations And Listening To Others." Instructional Science 39 (2): 189-204.

Bloom, B. S. 1974. The Taxonomy of Educational Objectives: Affective and Cognitive Domains. New York: David Mckaycompany, Inc.

Brockbank, A. And Mcgill, I. 1998. Facilitating Reflective Learning In Higher Education. Milton Keynes: SRHE and Open University Press.

Burke, A. 2011. "Group Work: How to Use Groups Effectively" Journal of Effective Teaching 11 (2): 87-95.

Brewer, E. W. 1997. 13 Proven Ways to Get Your Message Across: The Essential Reference for Teachers, Trainers, Presenters, and Speakers. California: Corwin Press, Inc.

Cooper, J. L. 1995. “Cooperative Learning and Critical Thinking" Teaching of Psychology. 22 (1): 7-9.

Corden, R. 2001. "Group Discussion and The Importance of A Shared Perspective: Learning From Collaborative Research" Qualitative Research 1(3): 347-367.

Donald Norman. 1980. "'Cognitive Engineering and Education' in Problem Solving and Education: Issues in Teaching and Research." Science 4: 1 - 32.

Ebrahim, A. 2012. "The Effect of Cooperative Learning Strategies on Elementary Students' Science Achievement and Social Skills in Kuwait." International Journal of Science and Mathematics Education 10 (2): 293-314.

Ennis, R. H. 1985. "A Logical Basis for Measuring Critical Thinking Skills" Educational Leadership 43 (2): 44-48.

Fisher, K. 2003. "Demystifying Critical Reflection: Defining Criteria For Assessment" Higher Education Research And Development 
22 (3): 313-324

Florea, N. M., \& Hurjui, E. 2014. "Critical Thinking in Elementary School Children" Issues 7 (9).

Fung, D. C. L., To, H., \& Leung, K. 2016. "The Influence of Collaborative Group Work On Students' Development of Critical Thinking: The Teacher's Role in Facilitating Group Discussions." Pedagogies: An International Journal 11 (2): 146-166.

Fung, D., \& Howe, C. 2014. "Group Work and The Learning of Critical Thinking in The Hong Kong Secondary Liberal Studies Curriculum." Cambridge Journal of Education 44 (2): 245-270.

Gillies, R. M. 2003. "Structuring Cooperative Group Work in Classrooms." International Journal Of Educational Research 39 (1): 35-49.

Gillies, R. M., \& Boyle, M. 2010. “Teachers' Reflections on Cooperative Learning: Issues Of Implementation." Teaching And Teacher Education 26 (4): 933-940.

Gokhale, A. A. 1995. "Collaborative Learning Enhances Critical Thinking." http://Scholar.Lib.Vt.Edu/Ejournals/JTE/V7n1/ Gokhale.Jte-V7n1.Html?Ref=Sawos.Org

Gossett, M., \& Fischer, 0. 2005. "Bringing Together Critical Thinking and Cooperative Learning Between Two Schools." Strategies 19 (2): 27-30.

Hilvano, N. T., Mathis, K. M., \& Schauer, D. P. 2014. "Collaborative Learning Utilizing Case-Based Problems.” Bioscience: Journal of College Biology Teaching 40 (2): 22-30.

Hughes, J. N., And Chen, Q. 2011. "Reciprocal Effects of StudentTeacher and Student-Peer Relatedness: Effects on Academic Self-Efficacy." Journal of Applied Developing Psychology 32 (5): 278-287.

Hummel, J. 1998. "Piaget's Theory of Cognitive Development." Educational Psychology Interactive 3(2): 1-5.

Jones, J. M. 2014. “Discussion Group Effectiveness Is Related to Critical Thinking Through Interestand Engagement" Psychology 
Learning \& Teaching 13 (1): 12-24.

Karami, M., Pakmehr, H., \&Aghili, A. 2012. "Another View to Importance of Teaching Methods in Curriculum: Collaborative Learning and Students' Critical Thinking Disposition." Procedia-Social and Behavioral Sciences 46: 3266-3270.

Kettler, T. 2014. “Critical Thinking Skills Among Elementary School Students Comparing Identified Gifted and General Education Student Performance." Gifted Child Quarterly 58 (2): 127-136.

Lai, E. R. 2011. “Critical Thinking: A Literature Review.” Pearson's Research Reports 6: 40-41.

Lee, H., Parsons, D., Kwon, G., Kim, J., Petrova, K., Jeong, E., \&Ryu, H. 2016. "Cooperation Begins: Encouraging Critical Thinking Skills Through Cooperative Reciprocity Using A Mobile Learning Game." Computers \& Education 97: 97-11.

Liberante, L. 2012. "The Importance of Teacher-Student Relationships, As Explored Through the Lens Of The NSW Quality Teaching Model." Journal of Student Engagement: Education Matters 2 (1): 2-9.

Lochhead, J., \& Clement, J. 1979. Cognitive Process Instruction. Research On Teaching Thinking Skills. Philadelphia, PA: Franklin Institute Press.

Macknight, C. B. 2000. "Teaching Critical Thinking Through Online Discussions." Educause Quarterly 23 (4): 38-41.

Malamitsa, K., Kasoutas, M., \& Kokkotas, P. 2009. "Developing Greek Primary School Students' Critical Thinking Through an Approach of Teaching Science Which Incorporates Aspects of History of Science." Science \& Education 18 (3-4): 457-468.

Mason, M. (ed.). 2008. Critical Thinking and Learning. Oxford: Blackwell Publishing.

Massa, S. 2014. "The Development of Critical Thinking in Primary School: The Role of Teachers' Beliefs." Procedia-Social and Behavioral Sciences 141: 387-392.

Matchett, N. J. 2009. “Cooperative Learning, Critical Thinking, and Character: Techniques to Cultivate Ethical Deliberation." Public 
Integrity 12 (1): 25-38

Mercer, N. 2008. "The Seeds of Time: Why Classroom Dialogue Needs A Temporal Analysis." The Journal of The Learning Sciences 17 (1): 33-59.

Mohammadjani, F., \& Tonkaboni, F. 2015. "A Comparison Between the Effect of Cooperative Learning Teaching Method And Lecture Teaching Method on Students' Learning and Satisfaction Level." International Education Studies 8 (9): 107.

Monique, Lok and Beatrice, Chiu, 2012. "Using Group Discussion as an Intervention Strategy in Novel Teaching to Study Students' Attitudinal Changes". http://edb.org.hk/HKTC/Download/ Journal/J11/Hktcjv11_15-C01.pdf._

Moon, J. 2007. Critical Thinking: An Exploration of Theory and Practice. New York, Routledge.

Nelson, C. E. 1994. "Critical Thinking and Collaborative Learning." New Directions for Teaching and Learning 1994 (59): 45-58.

Oakley, L. 2004. Cognitive Development. New York, Routledge.

Orprayoon, S. 2014. "Effects of Cooperative Learning on Learning Achievement and Group Working Behavior of Junior Students In Modern French Literature Course." Journal of Effective Teaching 14 (1): 80-98.

Peters, J. M. and Armstrong, J. L. 1998. “Collaborative Learning: People Laboring Together To Construct Knowledge." New Directions for Adult and Continuing Education 1998 (79): 75-85.

Phillips, V. and Bond, C. 2004 “Undergraduates' Experiences of Critical Thinking'" Higher Education Research and Development 23 (4): 277-294.

Ristiasari, T., Priyono, B., \& Sukaesih, S. 2012. "Model Pembelajaran Problem Solving Dengan Mind Mapping terhadap Kemampuan Berpikir Kritis Siswa." Unnes Journal of Biology Education 1 (3).

Roseth, C. J., Johnson, D. W., \& Johnson, R. T. 2008. “Promoting 
Early Adolescents' Achievement and Peer Relationships: The Effects Of Cooperative, Competitive, And Individualistic Goal Structures." Psychological Bulletin 134 (2): 223.

Rosnawati, R. 2009. “Enam Tahapan Aktivitas Dalam Pembelajaran Matematika Untuk Mendayagunakan Berpikir Tingkat Tinggi Siswa." In Seminar Nasional Penelitian, Pendidikan, Dan Penerapan MIPA 2009.

Sanasuttipu, W.,Tungjairob V., Musiksukont, S., Lerthamatewe W., Chanwatana, B. 2009." Effectiveness of Small Group Discussion on Critical Thinking, Self-Directed Learning, and Learning Satisfaction of Thai Nursing Students." Journal of Nursing Science 27 (3): 8-14

Schafersman, S. D. 1991. "An Introduction to Critical Thinking." http:/ / facultycenter.ischool.syr.edu/Wp-Content/ Uploads/2012/02/Critical-Thinking.Pdf Retrieved March, 3, 2008.

Siegel, H. 1991. Educating Reason: Rationality, Critical Thinking, and Education. New York: Routledge.

Smith, K. A. 1996. "Cooperative Learning: Making "Groupwork" Work." New Directions for Teaching and Learning 1996 (67): 71-82.

Saiz, C., Rivas, S. F., \& Olivares, S. 2015. "Collaborative Learning Supported by Rubrics Improves Critical Thinking." Journal of The Scholarship of Teaching and Learning 15 (1): 10-19.

Shahrill, M. 2013. "Review of Teacher Questioning in Mathematics Classrooms." International Journal of Humanities and Social Science 3 (17): 224-231.

Tan, S. C., Turgeon, A. J., \& Jonassen, D. H. 2001. "Develop Critical Thinking in Group Problem Solving Through ComputerSupported Collaborative Argumentation: A Case Study." Journal of Natural Resources and Life Sciences Education 30: 97.

Wolfolk, A.E. 1996. Educational Psychology: How Children Think and Learn, 2nd Edition. Oxford: Blackwell Publishing. 